\title{
Effectiveness of Computer Assisted Training of Patients Undergoing Lumbar Disc Herniation Surgery
}

\author{
Zuhal ERDOGAN, Hulya BULUT \\ Gazi University, Faculty of Health Sciences, Department of Nursing, Ankara, Turkey \\ This study has been presented at the $5^{\text {th }}$ International $16^{\text {th }}$ National Nursing Congress of Ankara University, Faculty of Health Sciences between 6 and 8 \\ November 2017 at Ankara, Turkey.
}

Corresponding author: Zuhal ERDOGAN z_ulusan@hotmail.com, zuhalerdogan2012@gmail.com

\section{ABSTRACT}

AIM: To identify the effects of computer assisted training schemes provided to patients who have undergone surgical intervention for lumbar disc herniation on their level of knowledge, level of anxiety, problems experienced after discharge, and level of functional incapacity.

MATERIAL and METHODS: The study was performed as a randomized controlled invasive study with a pre-test-post-test design. The study was conducted with 62 patients, 31 of which were included in the intervention group and 31 in the control group. Training and counselling were provided to the patients included in the intervention group via a training web-site, while a training guidebook with the same content as the website for patients was given to the patients included in the control group.

RESULTS: The patients who have undergone a surgical intervention for lumbar disc herniation, those who were provided computer assisted training were better informed, had better functional capacity, and experienced less anxiety after discharge than those who were only informed through the training guidebook.

CONCLUSION: Computer-assisted training was efficient educational tool for patients undergoing lumbar disc herniation surgery.

KEYWORDS: Computer-assisted training, Lumbar disc herniation, Patient education, Surgery

\section{INTRODUCTION}

L umbar disc herniation (LDH), a disease of significant concern with high recurrence rates, negatively affects the quality of life of patients and causes substantial labor and economic damage $(2,20,23,33)$. In certain cases, $\mathrm{LDH}$ can be medically treated and assistance can be provided to the patient through physiotherapy. However, for cases in which medical therapy fails to yield the desired outcomes, surgical intervention can be considered $(12,17)$. Although surgical intervention can achieve the desired outcomes in most cases, it can result in problems in certain cases. Karadag and Aksoy reported that patients who had undergone surgery for LDH experienced problems in the recovery phase, including pain, numbness, and tingling sensations (22). To overcome these negative outcomes, patients should be provided with effective training, and the information needs of patients must be focused on specifically $(22,30)$.

At present, advances in information technology have led to changes in the training schemes intended for patients; computer- and web-based training programs have been implemented more widely, replacing training provided via face-to-face sessions in the past (11).

With internet access, people can obtain information from websites when making decisions regarding their health. Fox and Duggan showed that one in every three adults in the USA uses the Internet to obtain information for themselves when they have health concerns (15). A previous study provided evidence that $66.3 \%$ of the Turkish population used the internet to search for information regarding health concerns (38). 
Training and counseling schemes provided on the internet are reportedly effective at increasing the self-efficacy and functional activity of patients who have undergone hip prosthesis implantation (42), reducing weight in patients who are overweight and have hypertension (5), reducing symptom load in patients with ovarian cancer (13), and providing better information to patients diagnosed with breast cancer (32). Computer-assisted patient training is an area that is being increasingly investigated by several research groups in Turkey. A previous study conducted in Turkey showed that computerassisted health training and counseling programs performed by nurses were effective for prostate cancer screening (9) as well as among expectant mothers (43), patients with diabetes (3), and patients with cardioverter defibrillators (41). However, a review of previous research showed that there has been no investigation regarding the effectiveness of computer-assisted training intended for patients who have undergone surgery for $\mathrm{LDH}$.

Patient care following surgery involves a long rehabilitation process, during which patients may experience several problems. The quality of patient care can probably be improved if computer-assisted patient-training programs are offered to patients who have undergone surgery for LDH to refresh their knowledge and provide answers to their questions.

\section{MATERIAL and METHODS}

\section{Design}

The study was a randomized, controlled intervention study with a pre-test/post-test design to investigate the effects of computer-assisted training provided to patients undergoing surgery for LDH on their levels of information, anxiety, functional incapacity, and the problems experienced following discharge.

\section{Samples}

The study was performed in the Neurosurgery Clinic of a university hospital in Turkey between September 2014 and June 2016. The inclusion criteria were as follows: undergoing surgery for LDH for the first time, being literate, being $>18$ years of age, being able to communicate, being capable of using a computer and accessing the Internet in daily life, and agreeing to participate in the study. The power of the study was determined to be $85 \%$ with $\alpha=0.05$.

Layered random sampling was used in the present study. The patients were grouped into intervention and control groups using lists of random numbers in a block randomization list $(n=62)$. To provide homogeneity in the intervention and control groups, the patients were grouped on the basis of age, gender and educational background (Figure 1).

\section{Data Collection}

The following list comprises the data collection tools used in the present study:

Patient information form: This form was designed by the researcher based on previous literature $(6,7,17,22,27,29,44)$, which gathered personal details about the patients, their diseases, and the surgical interventions they had undergone.
Information assessment form: This form was prepared by the researcher, was compatible with the training content and learning targets and included 48 questions.

Oswestry Disability Index (ODI): This scale comprises 10 questions and is used to investigate to what extent lumbar pain affects the daily activities of the patient. The higher the total score, the lower the level of functional effectiveness and the higher the level of disability $(8,14,45)$.

In a study performed in Turkey, Yakut et al. applied the ODI scale to patients who suffered from lumbar pain and reported (without indicating the related etiology) that it was reliable in a patient population with complaints of lumbar pain (40).

State-Trait Anxiety Inventory: The State-Trait Anxiety Inventory, a self-assessment inventory designed by Spielberger et al. (1970), was used to measure the trait and state anxiety along two separate sub-scales, with 20 questions in each $(28,31)$.

The validity and reliability of the State-Trait Anxiety Inventory were confirmed by Oner and LeCompte. The reliability coefficients were between .83 and .87 for the Trait Anxiety Scale and between .94 and .96 for the State Anxiety Scale (28).

Problems following discharge: A form was designed by the researcher based on the literature $(6,7,17,22,27,29,44)$ to identify problems that patients undergoing surgery for LDH may experience following discharge.

Patient-training guidebook and design of the site for patients with $L D H$ : The researcher prepared a patient-training guidebook compatible with the information needs of a patient who has undergone surgery for LDH and the learning targets set for them; its content was then entered on the patient website. The videos and photos on the website were taken in a laboratory environment with a professional team, who then edited the images. Following editing of the videos, sound editing was performed to complete the production of the multimedia material. The next step was the acquisition by the researcher of the web domain required for the computer-based training. MySQL was used by the web designer as the edited database for the algorithms used in the website to place the training content and the images on the Internet with PHP (Hypertext PreProcessor). On the training website, users were able to navigate the site using training menus, ask questions, access answers to frequently asked questions, complete questionnaires, use a personal message box, and see relayed messages and announcements following from the instructions for use.

\section{Intervention}

Informed consent was obtained from patients admitted to the clinic for surgery who met the sample criteria and who agreed to participate in the study. The patients then completed the questionnaire during interviews that lasted 25-40 minutes. The patients then watched videos under the headings "Your disease," "Preparation for surgical intervention," and "The hospitalization process," during which they were able to ask questions and gain information. The patients were registered on the website under a username and password, and the address of the website and the patients' user name and 


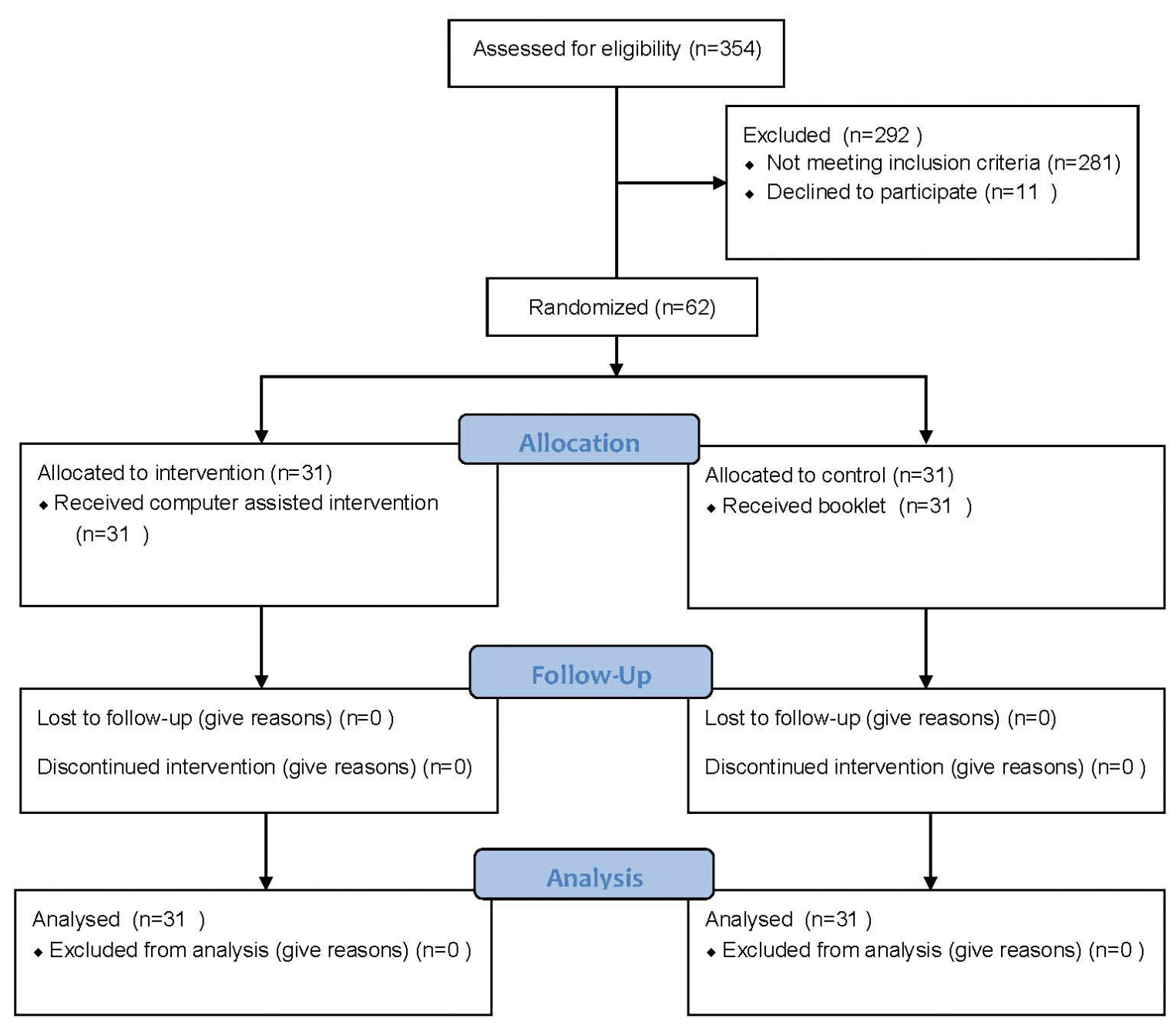

Figure 1: Consort flow diagram of study.

password were relayed via SMS to their phones. A visit to the patients was made on the day following surgery, during which time they were shown videos on the recovery period at home following discharge, and their questions were answered. The patients were asked to answer the survey questions again 15 days, 1 month and 3 months following surgery by adding the questions to the questionnaire section of the website and informing patients of this via SMS communication. Patients in the control group were provided with a patient-training guidebook containing the same content as the patienttraining website for patients with $\mathrm{LDH}$. The questions were readdressed to these patients through telephone interviews by the researcher.

\section{Ethical Considerations}

Consent was obtained from the relevant Ethics Committee (dated 01.04.2014, no. 25901600/1413). Patients were informed of the objectives of the study. Prior verbal and written consent was obtained from patients.

\section{Data Analysis}

The statistical analysis of data was performed using SPSS 20.0 (SPSS Inc., Chicago, IL, USA). As the parameters showed normal distributions upon reviewing the differences between the groups, an independent $t$-test was used for statistical analysis. For the analysis of more than two dependent parameters, Friedman's two-way ANOVA was used as the data did not show a normal distribution. In cases where a significant difference was found, the parameters showing a difference were defined using multiple comparison tests. As the parameters did not present with a normal distribution, the Mann-Whitney $U$ test was used to examine the differences between groups and a Wilcoxon test was used to examine the differences between two dependent parameters. Repeated-measures ANOVA was used to analyze repeated measurements, and in cases where significant differences were found, the measurements identified with differences were defined using a pairwise test. $p<0.05$ was considered to indicate a statistically significant difference. 


\section{RESULTS}

\section{Sociodemographic Data}

The demographic characteristics of the patients are shown in Table I. No statistically significant difference was found between the groups ( $p>0.05)$.

\section{Information Scores}

As shown in Table II, both groups had higher scores on levels of information following admission to the clinic. The results also showed that the patients in the intervention group had significantly higher scores for their level of information following discharge than those in the control group $(p<0.05)$ and that their level of information continually increased until the end of the first month $(p<0.05)$, with an increase in the following period that did not differ significantly.

\section{ODI Scores}

As shown in Table III, the functional capacities of both groups increased over time. However, reviewing the table in detail revealed that the increase in functional capacity following discharge for patients in the intervention group was significantly higher than that for patients in the control group $(p<0.05)$.

\section{Anxiety Scores}

As shown in Table IV, the state anxiety scores decreased in both the intervention and control groups over time, however, the decrease in the intervention group was statistically significant $(p<0.05)$.

It was also found that the trait anxiety score of the intervention group was significantly lower than that of the control group $(p<0.05)$ and that it decreased over time, whereas the trait anxiety score of the control group was similar to that recorded at the time of admission to the clinic, even 3 months after surgery.

\section{Correlation Analysis}

Correlation analysis between information and ODI scores of the intervention and control groups.

The results revealed a statistically significant association

Table I: Socio-Demographic Characteristics of Patients

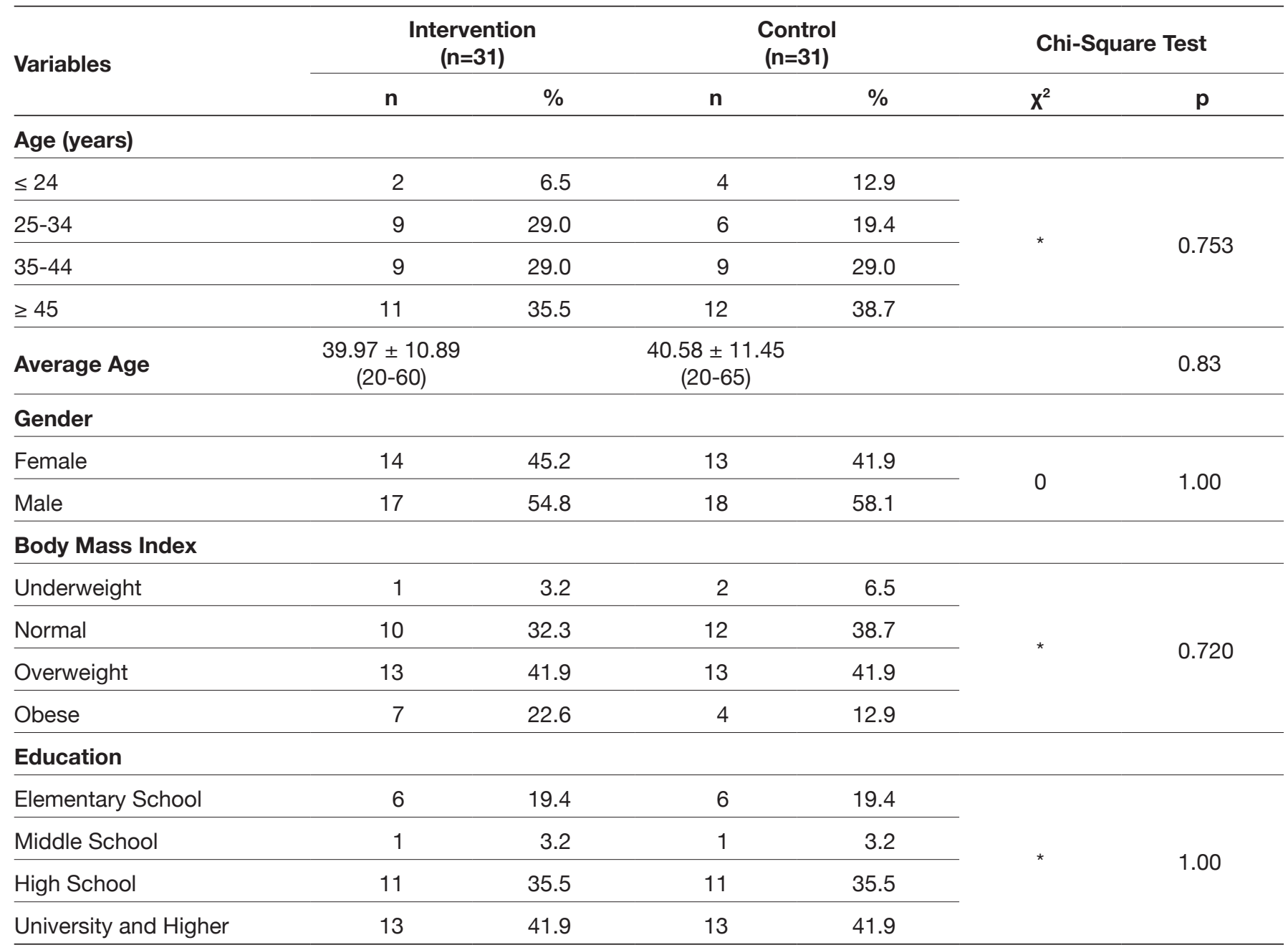

${ }^{*}$ As $20 \%$ of the expected values in boxes turned out to be smaller than 5 , chi-square analysis was performed using Monte Carlo simulation. 
Table II: Means of the Information Measures of the Patients Undergoing Surgery for LDH

\begin{tabular}{|c|c|c|c|c|c|}
\hline \multirow{2}{*}{ Group } & $\begin{array}{c}\text { Admission to the } \\
\text { Clinic }\end{array}$ & $\begin{array}{c}15 \text { days after the } \\
\text { surgery }\end{array}$ & $\begin{array}{c}1 \text { month after the } \\
\text { surgery }\end{array}$ & $\begin{array}{c}3 \text { months after the } \\
\text { surgery }\end{array}$ & \multirow{2}{*}{$\begin{array}{l}\text { p-value within } \\
\text { group }\end{array}$} \\
\hline & $\begin{array}{c}\text { Mean } \pm \text { SD } \\
(\text { Min-Max) }\end{array}$ & $\begin{array}{c}\text { Mean } \pm \text { SD } \\
(\text { Min-Max) }\end{array}$ & $\begin{array}{c}\text { Mean } \pm \text { SD } \\
(\text { Min-Max) }\end{array}$ & $\begin{array}{c}\text { Mean } \pm \text { SD } \\
(\text { Min-Max) }\end{array}$ & \\
\hline Intervention & $\begin{array}{c}34.84 \pm 3.29^{a} \\
(27-42) \\
\end{array}$ & $\begin{array}{c}44.84 \pm 3.21^{b} \\
(37-48)\end{array}$ & $\begin{array}{c}45.97 \pm 2.75^{c} \\
(38-48)\end{array}$ & $\begin{array}{c}46.74 \pm 2.19^{c} \\
(40-48)\end{array}$ & $p=0.001^{*}$ \\
\hline Control & $\begin{array}{c}34.06 \pm 4.79^{a} \\
(24-45)\end{array}$ & $\begin{array}{c}41.45 \pm 4.51^{\mathrm{b}} \\
(33-48)\end{array}$ & $\begin{array}{c}41.68 \pm 4.74^{b} \\
(33-48)\end{array}$ & $\begin{array}{c}41.61 \pm 4.54^{b} \\
(32-48)\end{array}$ & $p=0.001^{*}$ \\
\hline $\begin{array}{l}p \text {-value } \\
\text { between groups }\end{array}$ & $\begin{array}{c}p=0.461^{\star *} \\
t=0.742\end{array}$ & $\begin{array}{c}p=0.003^{* * *} \\
z=-2.926\end{array}$ & $\begin{array}{c}p=0.001^{* * *} \\
z=-4.023\end{array}$ & $\begin{array}{c}p=0.001^{* * *} \\
z=-5.057\end{array}$ & \\
\hline
\end{tabular}

*Friedman's two-way ANOVA, Wilcoxon signed-rank test with Bonferroni correction, **Independent $t$-test, ***Mann-Whitney $U$ test.

$a, b, c, d$ : Different letters represent statistically significant differences $(p<0.05)$.

Table III: Distribution of Patients' Scores on the Oswestry Disability Index

\begin{tabular}{|c|c|c|c|c|c|}
\hline \multirow{2}{*}{ Group } & $\begin{array}{c}\text { Admission to the } \\
\text { Clinic }\end{array}$ & $\begin{array}{c}15 \text { days after the } \\
\text { surgery }\end{array}$ & $\begin{array}{c}1 \text { month after the } \\
\text { surgery }\end{array}$ & $\begin{array}{c}3 \text { months after the } \\
\text { surgery }\end{array}$ & \multirow[b]{2}{*}{$\begin{array}{c}\text { p-value within } \\
\text { group }\end{array}$} \\
\hline & $\begin{array}{c}\text { Mean } \pm \text { SD } \\
(\text { Min-Max) }\end{array}$ & $\begin{array}{c}\text { Mean } \pm \text { SD } \\
(\text { Min-Max) }\end{array}$ & $\begin{array}{c}\text { Mean } \pm \text { SD } \\
(\text { Min-Max) }\end{array}$ & $\begin{array}{c}\text { Mean } \pm \text { SD } \\
(\text { Min-Max) }\end{array}$ & \\
\hline Intervention & $\begin{array}{c}52.83 \pm 17.05^{a} \\
(12-84.4)\end{array}$ & $\begin{array}{c}38.1 \pm 17.27^{b} \\
(4-68)\end{array}$ & $\begin{array}{c}24.26 \pm 14.58^{c} \\
(2-60)\end{array}$ & $\begin{array}{c}17.71 \pm 11.47^{d} \\
(0-54)\end{array}$ & $p=0.001^{*}$ \\
\hline Control & $\begin{array}{c}54.12 \pm 18.84^{a} \\
(6-90)\end{array}$ & $\begin{array}{c}47.65 \pm 17.55^{a} \\
(12-73.3)\end{array}$ & $\begin{array}{c}34.55 \pm 16.91^{b} \\
(0-62.2)\end{array}$ & $\begin{array}{c}27.69 \pm 16.83^{c} \\
(0-62.2)\end{array}$ & $p=0.001^{*}$ \\
\hline$p$-value & $p=0.778^{\star *}$ & $p=0.023^{\star \star *}$ & $p=0.013^{* *}$ & $p=0.009^{\star * *}$ & \\
\hline between groups & $t=-0.283$ & $z=-2.276$ & $t=-2.567$ & $z=-2.594$ & \\
\hline
\end{tabular}

${ }^{*}$ Friedman's two-way ANOVA, Wilcoxon signed-rank test with Bonferroni correction, **Independent t-test, ***Mann-Whitney U test.

$a, b, c, d$ : Different letters represent statistically significant differences $(p<0.05)$.

Table IV: Mean Scores of the Patients on State and Trait Anxiety in Connection with Lumbar Disc Herniation Surgery

\begin{tabular}{|c|c|c|c|c|c|c|}
\hline & \multirow{2}{*}{ Group } & \multirow{2}{*}{$\begin{array}{c}\text { Admission to the } \\
\text { Clinic } \\
\text { Mean } \pm \text { SD } \\
\text { (Min-Max) }\end{array}$} & \multirow{2}{*}{$\begin{array}{c}15 \text { days after the } \\
\text { surgery } \\
\begin{array}{c}\text { Mean } \pm \text { SD } \\
\text { (Min-Max) }\end{array} \\
\end{array}$} & \multirow{2}{*}{$\begin{array}{c}1 \text { month after the } \\
\text { surgery } \\
\text { Mean } \pm \text { SD } \\
\text { (Min-Max) }\end{array}$} & \multirow{2}{*}{$\begin{array}{c}3 \text { months after } \\
\text { the surgery } \\
\text { Mean } \pm \text { SD } \\
\text { (Min-Max) }\end{array}$} & \multirow{2}{*}{$\begin{array}{c}\text { Statistical } \\
\text { Analysis }\end{array}$} \\
\hline & & & & & & \\
\hline Intervention & State Anxiety & $\begin{array}{c}50.42 \pm 11.91 \\
(27-75)\end{array}$ & $\begin{array}{c}38.55 \pm 8.4 \\
(20-55)\end{array}$ & $\begin{array}{c}33.23 \pm 8.14 \\
(20-50)\end{array}$ & $\begin{array}{c}30.55 \pm 6.75 \\
(20-50)\end{array}$ & $p=0.001^{*}$ \\
\hline Control & $\begin{array}{l}\text { Statistical } \\
\text { Analysis }\end{array}$ & $\begin{array}{c}p=0.6^{\star *} \\
t=-0.527\end{array}$ & $\begin{array}{c}p=0.002^{* *} \\
t=-3.267\end{array}$ & $\begin{array}{c}p=0.001^{* * *} \\
z=-4.188\end{array}$ & $\begin{array}{c}p=0.001^{\star * *} \\
z=-4.456\end{array}$ & \\
\hline Intervention & Trait Anxiety & $\begin{array}{c}40.39 \pm 7.11 \\
(27-58)\end{array}$ & $\begin{array}{c}38.71 \pm 6.76 \\
(24-53)\end{array}$ & $\begin{array}{c}38.26 \pm 7.41 \\
(23-55)\end{array}$ & $\begin{array}{c}37.29 \pm 7.25 \\
(21-54)\end{array}$ & $\mathrm{p}=0.001^{\star \star \star *}$ \\
\hline
\end{tabular}

${ }^{*}$ Friedman's two-way ANOVA, ${ }^{* *}$ Independent $t$-test, ${ }^{* *}$ Mann-Whitney $U$ test, ${ }^{* * * * R e p e a t e d-m e a s u r e s ~ A N O V A . ~}$ 
between the information levels and ODI scores of the intervention group recorded in the first month $(r=-0.377$, $\mathrm{p}=0.036$ ), with the ODI score decreasing as the information score of the intervention group increased.

\section{Correlation analysis between state and trait anxiety scores and $O D I$ scores of the intervention and control groups.}

The correlation analysis between the state anxiety scores and ODI scores for the intervention and control groups revealed a statistically significant association for all the measurements of the intervention group (day 15: $r=0.565, p=0.001 ; 1$ month: $r=0.529, p=0.002 ; 3$ months: $r=0.490, p=0.005)$ and those of the control group (day 15: $r=0.562, p=0.001$; 1 month: $r=0.751$, $p=0.0001$; 3 months: $r=0.798, p=0.0001$ ). In both groups, the ODI scores increased in parallel with the state anxiety scores.

The correlation analysis between the trait anxiety scores and the ODI scores of the intervention and control groups revealed a statistically significant association between the anxiety score and the ODI score of the control group in the third month $(r=0.416, p=0.02)$, with the ODI score of the control group increasing with increased anxiety scores.

\section{Correlation analysis between information scores and the state/trait anxiety scores of the intervention and control groups.}

Correlation analysis of the information scores and state/trait anxiety scores of the intervention and control groups revealed a statistically significant association between the information and state anxiety scores recorded in the first month $(r=-0.365$, $\mathrm{p}=0.044$ ) and trait anxiety scores recorded in the first month $(r=-0.435, p=0.014)$. In the intervention group for the first month, the state and trait anxiety scores recorded decreased with increases in the information scores.

Correlation analysis of information scores and state anxiety scores of the control group showed the existence of a statistically significant association for all the measurements (day 15 day: $r=-0.595, p=0.0001 ; 1$ month: $r=-0.593$, $p=0.0001 ; 3$ months: $r=-0.693, p=0.0001)$. The state anxiety score decreased with increasing information score.

\section{Problems Experienced}

The present study found that the six most frequent problems that patients in the intervention and control groups experienced in the monitoring phase were pain, pain in the legs, sleep disorders, loss of sensation, a decrease in social activities and difficulties in maintaining a normal routine in working life. It was also found that the patients in the two groups experienced similar problems and that the intensity of problems that patients in the intervention group experienced gradually faded in the third month.

\section{DISCUSSION}

$\mathrm{LDH}$ is a health problem that impacts the quality of life and daily routine of patients, both pre- and post-operatively. Therefore, it is important that patients are well-informed. In a qualitative study of the experiences of patients who had undergone spinal surgery (10), patients particularly emphasized that they wanted to be duly informed prior to, and following surgery, further underlining that the delivery of information was imperative. Almost all patients $(93.5 \%$ in the intervention group and all patients in the control group) who participated in the present study stated that they wanted to be duly informed. Following surgery for LDH, the daily routine of patients is substantially restricted due to pain. Furthermore, patients do not know how to care for the operated area, or what is required for effective pain management, highlighting areas that they should be fully informed about (4). A lack of information increases patient uncertainty, causing their homecare to be more stressful (10). The results of the present study indicate that all patients had high levels of state anxiety upon admission to the clinic (Table IV). This result is an important indicator showing that patients experience anxiety due to uncertainty. The results also demonstrated that patients often experienced problems including pain, difficulty sleeping, loss of sensation, decreases in social activities, and difficulties in sustaining their work. Similarly, Karadag and Aksoy reported that patients in recovery following surgery experienced pain, numbness and tingling sensations (22).

Previous research has reported that training of patients undergoing surgery is important for promoting their daily routine, increasing their level of understanding, quality of life, self-care capacity and satisfaction, and decreasing the problems they experience $(16,22,30,35,44)$. At present, in addition to verbal training, written materials and videos, multimedia-based training, including CD-ROMs, DVDs, and the Internet are currently used as patient-training tools. Videos used in multimedia-based training allow patients to be involved in independent activities with friends and relatives outside the clinic environment. Through repetitive content in video-based training materials, patients can consolidate their knowledge and easily put what they have learned into practice (1). A review of previous research indicates that there has been no investigation of the effects of computer-based training programs intended for patients who have undergone surgery for LDH. Therefore, comparative results obtained in studies investigating the effects of computer-based training and training through brochures for other diseases and surgical interventions have been discussed here. Several researchers have reported that computer-based interactive training programs can be used more effectively to enhance patient knowledge, including in patients with burns (24), patients with prostate cancer (34), orthopedic patients (19), and patients with breast cancer (32).

The present study also found that, although both groups had high information scores, patients who received computerassisted training had significantly higher information scores following discharge than those in the control group, and their level of knowledge increased over time (Table II). It appears that the higher scores in the intervention group can be attributed to their more frequent use of audiovisual training methods due to their entertaining content. An additional advantage of such programs is that patients can watch videos numerous times to consolidate their knowledge. The majority of patients in the present study stated that they had enjoyed Internet-based training and would recommend participating in such training programs to other patients. 
The ODI is a tool developed to investigate the extent to which lumbar pain affects the daily activities of a patient (18); it has been demonstrated that the mean ODI score of patients suffering from chronic lumbar pain was 35.75 and that patients were heavily dependent $(60 \%-80 \%)$ on others to perform their daily activities (45). Another study performed to investigate changes in ODI scores in patients who had undergone surgery for LDH provides additional evidence that patients had functional incapacities in personal care, lifting heavy objects, walking, sitting, standing, sleeping, sexual life, social life, and traveling. In the same study, in which patients were monitored for one year, the majority of changes in ODI scores ( $88 \%$ in women and $80 \%$ in men) occurred in the first 6 weeks (18). McGregor et al. reported that patients experienced problems in sustaining their daily life activities following discectomy (26).

Although both groups in the present study ultimately had improved functional capacity, the results show that the functional capacity following the discharge of patients who were trained using the computer-aided program was significantly higher than that of the patients who received the training guidebook only (Table III). The higher functional capacity of patients in the intervention group may be attributed to the fact that they experienced less pain, asked the researcher more questions, and had higher information scores due to the training videos on pain and movement, which enabled knowledge to be put into practice more easily. Correlation analysis of the information and ODI scores of the intervention and control groups revealed that the ODI decreased with the increase in information scores of the intervention group.

Regardless of the type of surgery performed, it is reported that the majority of patients (60-80\%) experience anxiety to a certain extent $(21,37)$. Anxiety is also one of the most frequently observed psychological problems in patients hospitalized for the surgical treatment of LDH (46). It was reported in a previous study that patients undergoing surgery for LDH had significantly higher levels of anxiety than individuals in the general population (25). In a study of patients who had undergone spinal surgery, Davis et al. reported that patients stated that they required more support and help following discharge, thereby underlining the importance of easier access to contact with health professionals. As patients were unsure of what to expect following discharge, they experienced uncertainty, disappointment and anxiety (10). Similarly, Williamson et al. found that patients who had undergone spinal surgery experienced anxiety relating to their uncertainty of how to conduct themselves in the postoperative period (39).

The effect of Internet-based interactive patient-training schemes on patient anxiety levels has been investigated previously. Many studies have shown that computer-based patient-training programs yielded effective results in reducing the anxiety levels of patients, including those on a waiting list for cardiac surgery (36), those with breast cancer (31), and those with burns (24).

Although both groups in the present study had low anxiety levels during the study duration, the results showed that the anxiety levels of patients following discharge who were trained using the computer-aided program were significantly lower than those of patients who received the training guidebook only (Table IV). The lower level of anxiety among patients in the intervention group than those in the control group may be ascribed to the fact that they experienced fewer problems, had higher functional capacity and information scores, and contacted the researcher more frequently. The correlation analysis between the anxiety scores and ODI scores of the intervention and control groups revealed that the ODI scores increased in parallel with the increase in anxiety score of the intervention and control groups, and that anxiety scores showed a downward trend in parallel to an increase in the information scores of the intervention and control groups.

\section{Limitations}

The present study had some limitations. First, patients in both the intervention and control groups had access to information at different Internet sites. Second, pre-operative training was interrupted during admission of patients to the clinic on the day of surgery.

\section{CONCLUSION}

The findings of the present study of patients undergoing surgery for LDH show that patients who were trained with a computer-assisted training program had higher levels of information, higher functional capacity, and reduced anxiety compared with those who received a training guidebook only.

\section{FUNDING}

The study was funded by Teaching Staff Training Program.

\section{REFERENCES}

1. Abed MA, Himmel W, Vormfelde, Koschack J: Video-assisted patient education to modify behavior: A systematic review. Patient Educ Couns 97(1):16-22, 2014

2. Andersen M, Ernst C, Rasmussen J, Dahl S, Carreon LY: Return to work after lumbar disc surgery is related to the lenght of preoperative sick leave. Dan Med J 64 (7):1-4, 2017

3. Avdal EU, Kizilci S, Demirel, N: The effect of web-based diabetes education on diabetes careresults: A randomized control study. Comput Inform Nurs 29(2):101-106, 2011

4. Aydogan N: Lomber disk hernisi nedeniyle cerrahi girişim uygulanan hastaların taburculuk aşamasındaki bilgi gereksinimleri (Unpublished dissertation), Ankara: Hacettepe University, 2005

5. Bennett GG, Herring SJ, Puleo E, Stein EK, Emmons KM, Gillman MW: Web-based weightloss in primarycare: A randomized controlled trial. Obesity (Silver Spring) 18(2):308313, 2010

6. Black J, Hawks J: Medical-Surgical Nursing Clinical Management for Positive Outcomes. America: Elsevier, 2009

7. Burke KM, Mohn-Brown E, Eby L: Medical-Surgical Nursing Care. New Jersey: Pearson Education, 2011 
8. Calik $Y$, Calik AF: Kronik bel ağrılı hastalarda nöropatik ağrının fonksiyonel yetersizlik üzerine etkisinin değerlendirilmesi. Turk J Osteoporos 21:122-126, 2015

9. Capik C, Gozum S: The effect of web-assisted education and reminders on health belief, level of knowledge and early diagnosis behaviors regarding prostate cancer screening. Eur J Oncol Nur 16(1):71-77, 2012

10. Davis RE, Vincent C, Henley A, McGregor A: Exploring the care experience of patients undergoing spinal surgery: $A$ qualitative study. J Eval Clin Pract 19(1):132-138, 2013

11. Demir Y, Gozum S: Sağlık eğitiminde yeni yönelimler; web destekli sağlık eğitimi. DEUHYO ED 4(4):196-203, 2011

12. Dodwad SN, Dodwad SJ, Savage JW: Lumbar discectomy review. Operative Techniques in Orthopaedics 25(3):177-186, 2015

13. Donovan HS, Ward SE, Sereika SM, Knapp JE, Sherwood PR, Bender CM, Edwards RP, Fields M, Ingel R: Web-based symptom management for women with recurrent ovarian cancer: A pilot randomized controlled trial of the write symptoms intervention. J Pain Symptom Manage 47(2):218230, 2014

14. Fairbank JC, Pynsent PB: The oswestry disability index. Spine (PhilaPa 1976) 25(22):2940-2952,2000

15. Fox S, Duggan M: Health online 2013. January 2013;1-55 Available from: http://www.pewinternet.org/2013/01/15/ health-online-2013/. Accessed December 19, 2017

16. Hartley M, Neubrander J, Repede E: Evidence-based spine preoperative education. International Journal of Orthopaedic and Trauma Nursing 16(2):65-75, 2012

17. Harvey CV: Spinal surgery patient care. Orthop Nurs 24(6):426440, 2005

18. Häkkinen $A$, Kautiainen $H$, Järvenpää $S$, Arkela-Kautiainen $\mathrm{M}$, Ylinen J: Changes in the total oswestry Index and its ten items in females and males pre- and post-surgery for lumbar disc herniation: A 1-year follow-up. Eur Spine J 16(3):347-352, 2007

19. Heikkinen K, Leino-Kilpi H, Taina N, Anne K, Sanna S: A comparison of two educational interventions for the cognitive empowerment of ambulatory orthopaedic surgery patients. Patient Educ Couns 73(2):272-279, 2008

20. Heindel P, Tuchman A, Hsieh PC, Pham MT, D'Oro A, Patel NN, Jakoi AM, Hah R, Liu JC, Buser Z, Wang JC: Reoperation rates after single-level lumbar discectomy. Spine 42(8):E496E501, 2017

21. Jlala HA, French JL, Foxall GL, Hardman JG, Bedforth NM: Effect of preoperative multimedia information on perioperative anxiety in patients under going procedures under regional anaesthesiology. Br J Anaesth 104(3):369-374, 2010

22. Karadag M, Aksoy G: Lomber disk hernisi ameliyatında hastaların evde iyileşmelerini hızlandırmada hemşirenin eğitici rolünün etkisi. Düşünen Adam 15(4):245-254, 2002

23. Khalsa K, Amorosa L: Recurrent discherniation: Etiology, evaluation, treatment, outcomes, and prevention (annular repair). Semin Spine Surg 28:37-42, 2016
24. Lo SF, Hayter M, Hsu M, Lin SE, Lin SI: The effectiveness of multimedia learning education programs on knowledge, anxiety and pressuregarment compliance in patients undergoing burns rehabilitation in Taiwan: An experimental study. J Clin Nurs 19(1-2):129-137, 2010

25. Löbner M, Luppa M, Matschinger H, Konnopka A, Meisel HJ, Günther L, Meixensberger J, Angermeyer MC, König $\mathrm{HH}$, Riedel-Heller S: The course of depression and anxiety in patients undergoing discsurgery: A long itudinal observational study. J Psychosom Res 72(3):185-194, 2012

26. McGregor AH, Dore CJ, Morris TP, Morris S, Jamrozik K: Function after spinal treatment, exercise and rehabilitation (FASTER): Improving the functional outcome of spinal surgery. BMC Musculoskelet Disord 26:11-17, 2010

27. Miers AG: Nontraumatic disorders of the spine. In: Barker E (ed), Neuroscience Nursing: A Spectrum of Care. USA: Elsevier Health Sciences, 2008:450-469

28. Oner N, LeCompte A: Durumluk-Sürekli Kaygı Envanteri El Kitabı. İstanbul: Boğaziçi Üniversitesi Yayınları, 1983

29. Ozbayir T: Nörolojik travmalar. In: Karadakovan A, Eti Aslan F (ed), Dahili ve Cerrahi Hastalıklarda Bakım. Ankara: Nobel Kitabevi, 2014:1217-1220

30. Papanastassiou I, Anderson R, Barber N, Conover C, Castellvi AE: Effects of preoperative education on spinal surgery patients. SAS Journal 5(4):120-124, 2011

31. Ryhänen $A M$, Rankinen $S$, Siekkinen $M$, Saarinen $M$, Korvenranta $\mathrm{H}$, Leino-Kilpi $\mathrm{H}$ : The impact of an empowering internet-based breast cancer patient pathway program on breast cancer patients' clinical outcomes: A randomised controlled trial. J Clin Nurs 22(7-8):1016-1025, 2013

32. Ryhänen AM, Siekkinen M, Rankinen S, Korvenranta H, LeinoKilpi H: The effects of internet or interactive computer-based patient education in the field of breast cancer: A systematic literature review. Patient Educ Couns 79(1):5-13, 2010

33. Saban KL, Penckofer SM, Androwich I, Bryant FB: Healthrelated quality of life patients following selected types of lumbar spinal surgery: A pilot study. Health Qual Life Outcomes 28:1-11, 2007

34. Salonen A, Ryhänen AM, Leino-Kilpi H: Educational benefits of internet and computer-based programmes for prostate cancer patients: A systematic review. Patient Educ Couns 94(1):10-19, 2014

35. Saritas S: Lomber disk hernisi ameliyatı olan hastalara verilen eğitimin yaşam kalitesi, öz-bakım gücü ve cinsel doyum üzerine etkisi (Unpublished dissertation). Erzurum: Atatürk University, 2011

36. Scherrer-Bannerman A, Fofonoff D, Minshall D, Downie S, Brown M, Leslie F, McGowan P: Web based education and support for patients on the cardiac surgery waitinglist. J Telemed Telecare 6(2):72-74, 2000

37. Tasdemir A, Erakgun A, Deniz MN, Certug A: Preoperatif bilgilendirme yapılan hastalarda ameliyat öncesi ve sonrası anksiyete düzeylerinin state-traitanxiety inventory test ile karşılaştırılması. Turk J Anaesth Reanim 41:44-49, 2013 
38. Türkiye İstatistik Kurumu: Hane halkı Bilişim Teknolojileri Kullanım Araştırması, 2015. Türkiye Sağlık Araştırması. August 18, 2015. Available at: http://www.webcitation.org/query?urI=http\%3A\%2F\%2Fwww.tuik.gov.tr\%2FPreHaberBultenleri. do\%3Fid\%3D18660\&date=2017-07-06. Accessed September 15, 2016

39. Williamson J, Bulley C, Coutts F: What do patients feel they can do following lumbar microdiscectomy? A qualitative study. Disabil Rehabil 30(18):1367-1373, 2008

40. Yakut E, Duger T, Oksuz C, Yorukan S, Ureten K, Turan D, Frat T, Kiraz S, Krd N, Kayhan H, Yakut Y, Guler C: Validation of the turkish version of the oswestry disability index for patients with lowback pain. Spine 29(5):581-585, 2004

41. Yardimci T, Mert H: Web-based intervention to improve implantable cardioverterdefibrillat or patients' shock-related anxiety and quality of life: A randomized controlled trial. Clin Nurs Res 28(2):150-164, 2019
42. Yeh ML, Chen $\mathrm{HH}$, Liu PH: Effects of multimedia with printed nursing guide in education on self-efficacy and functional activity and hospitalization in patients with hipreplacement. Patient Educ Couns 57(2):217-224, 2005

43. Yenal K, Sevil U: The effects of web-based child birth education program on activities of daily living of pregnant women. Health MED 6(3):930-938, 2012

44. Yildirim M: Lomber disk hernisi ameliyatı olan hastalar için geliştirilen hasta güvenliği öğretim planının hastaların günlük yaşam aktiviteleri ve yaşam kalitesi üzerine etkisi (Unpublished dissertation). Ankara: Hacettepe University, 2013

45. Yilmaz A, Altug F, Coskun E: Kronik bel ağrısı olan hastalarda ağrı, özürlülük durumu ve psikolojik faktörlerin incelenmesi. Turkiye Klinikleri J Med Sci 32(5):1278-1283, 2012

46. Yilmaz ER, Bulut SD, Eryilmaz F, Eser T, Alatas E, Eryilmaz G, Gurer B, Turkoglu E, Dolgun H: Beyin cerrahi servisinde lomber disk hernisi tanısı ile yatan hastalarda anksiyete - depresyon düzeyleri ve hasta iyileşmesi üzerinde etkileri. Ortadoğu Tıp Dergisi 6(3):111-121, 2014 